\title{
PENGARUH SIZE, LIKUIDITAS, RISIKO KREDIT DAN RENTABILITAS TERHADAP RASIO KECUKUPAN MODAL
}

\author{
Ayusta Riana Dewi ${ }^{1}$ \\ I Putu Yadnya ${ }^{2}$
}

\author{
${ }^{1,2}$ Fakultas Ekonomi Dan Bisnis Universitas Udayana (Unud), Bali, Indonesia \\ e-mail : ayustariana@yahoo.co.id
}

\begin{abstract}
ABSTRAK
Industri BPR yang sehat diperlukan dalam rangka menciptakan stabilitas sistem keuangan, dan mendorong pertumbuhan ekonomi nasional. Penelitian ini bertujuan untuk mengetahui pengaruh Size/ukuran bank, Loan to Deposit Ratio (LDR), Non Performing Loan (NPL) dan Net Interest Margin (NIM) terhadap Capital Adequacy Ratio (CAR). Penelitian ini dilakukan pada BPR di Provinsi Bali periode 2015-2016. Teknik pengambilan sampel menggunakan metode sensus yang berjumlah 137 BPR dengan teknik analisis data regresi linier berganda. Berdasarkan hasil analisis menunjukkan bahwa Size/ukuran bank berpengaruh negatif signifikan terhadap CAR. Hal ini menunjukkan bahwa semakin tinggi total asset suatu bank maka bobot risiko semakin tinggi dan kecukupan modalnya akan menurun. LDR dan NIM berpengaruh positif signifikan terhadap CAR. Hal ini menunjukkan bahwa semakin tinggi LDR dan NIM maka kecukupan modal akan meningkat. NPL berpengaruh negatif signifikan terhadap CAR. Hal ini menunjukkan bahwa semakin tinggi NPL maka kecukupan modal bank akan menurun.
\end{abstract}

Kata kunci: CAR, SIZE, LDR, NPL, NIM

\begin{abstract}
$B P R$ industry is needed in order to create financial system stability and fostering national economic growth.This study aims to determine the effect of bank size, Loan to Deposit Ratio (LDR), Non Performing Loan (NPL) and Net Interest Margin (NIM) to Capital Adequacy Ratio (CAR). This research was conducted at BPR in Bali Province period 2015-2016. The sampling technique used census method amounting to 137 BPR with multiple linear regression analysis technique. Based on the results of the analysis shows that the Size / size of the bank has a significant negative effect on CAR. This shows that the higher total assets of a bank the higher the risk weight and capital adequacy will decrease. LDR and NIM have a significant positive effect on CAR. This indicates that the higher LDR and NIM then the capital adequacy will increase. NPL has a significant negative effect on CAR. This shows that the higher the NPL, the adequacy of bank capital will decrease.
\end{abstract}

Keywords: CAR, SIZE, LDR, NPL, NIM 


\section{PENDAHULUAN}

Berdasarkan Undang-Undang (UU) Perbankan No.7 tahun 1992 sebagaimana telah diubah dengan UU No.10 tahun 1998, disebutkan bahwa berdasarkan jenis kegiatan usahanya, bank dapat dibagi menjadi dua yaitu Bank Umum dan Bank Perkreditan Rakyat (BPR). Perbedaan antara kedua bank tersebut dapat dilihat dari segi fungsinya, Bank umum merupakan bank yang melaksanakan kegiatan usahanya secara konvensional dan prinsip syariah dan memberikan jasa dalam lalu lintas pembayaran, sedangkan BPR tidak dapat memberikan jasa dalam lalu lintas pembayaran yang hanya menjalankan kegiatan usahanya secara konvensional atau syariah (Kasmir, 2014). Perbankan nasional yang tangguh, termasuk industri BPR yang sehat, kuat, efisien, dan memiliki daya saing, diperlukan dalam rangka menciptakan stabilitas sistem keuangan, mendorong pertumbuhan ekonomi nasional dan mendukung perkembangan usaha yang bersifat dinamis. Pemeliharaan sumber-sumber modal yang memadai dapat meningkatkan kepercayaan deposan, kreditur, dan pasar pendanaan, sehingga mendukung kesehatan dan kestabilan bank. BPR jika memiliki kondisi permasalahan struktural maka harus didukung dengan jumlah modal yang lebih besar dan berkualitas agar dapat menyerap potensi risiko yang dihadapi serta dalam rangka penguatan kelembagaan BPR.

Peraturan Bank Indonesia Nomor 8 / 18 / PBI / 2006 mengenai Kewajiban Penyediaan Modal Minimum (KPMM) merupakan salah satu upaya yang dilakukan untuk menguatkan permodalan BPR. Peraturan tersebut memuat mengenai rasio kecukupan modal yang digambarkan dengan CAR minimal bagi BPR adalah 8 persen untuk dapat dikategorikan BPR yang sehat. CAR adalah rasio yang 
menunjukkan kecupukan modal yang digunakan untuk mengantisipasi risiko kerugian yang mungkin akan dihadapi bank. Nilai CAR yang semakin tinggi menyebabkan kemampuan yang dimiliki bank untuk mengatasi risiko dari seluruh kredit aktiva produktif yang berisiko juga semakin tinggi.

Sejak tanggal 31 Desember 2013 sebagaimana diamanatkan dalam UU Nomor 21 Tahun 2011, Fungsi, tugas dan wewenang pengaturan dan pengawasan kegiatan jasa keuangan di sektor perbankan beralih dari Bank Indonesia ke Otoritas Jasa Keuangan. Otoritas Jasa Keuangan selanjutnya menyempurnakan ketentuan tentang ketentuan permodalan BPR melalui POJK Nomor 5 / POJK.03 / 2015. Penyempurnaan ketentuan permodalan BPR dilakukan dalam rangka meningkatkan kemampuan BPR dalam menyerap risiko melalui peningkatan kualitas permodalan dengan mewajibkan BPR untuk memenuhi rasio CAR minimal 12\%, meningkat dari ketentuan sebelumnya sebesar $8 \%$.

Menurut Dendawijaya (2009:121) CAR merupakan rasio yang menunjukkan besarnya total aktiva yang dimiliki bank yang mengandung unsur risiko (penyertaan, kredit, tagihan pada bank lain, surat berharga) yang dibiayai dengan modal sendiri maupun dana yang diperoleh dari sumber diluar bank. Darmawi (2011:91) menyebutkan bahwa salah satu komponen faktor permodalan adalah kecukupan modal. Rasio untuk menguji kecukupan modal bank dengan melakukan perbandingan rasio tersebut antara rasio modal terhadap Aset Tertimbang Menurut Risiko yang selanjutnya disebut ATMR. Modal merupakan salah satu faktor yang penting bagi BPR dalam rangka pengembangan usaha dan menyerap kemungkinan risiko kerugian. Kewajiban penyediaan modal minimum bagi BPR, yang 
selanjutnya disingkat KPMM, ditentukan berdasarkan risiko yang terkandung dalam aset neraca.

Menurut Riyanto (2008:313) ukuran perusahan adalah besar kecilnya perusahaan dilihat dari besarnya nilai penjualan atau nilai aktiva. Teori trade-off menyatakan bahwa apabila ukuran perusahaan meningkat, akan lebih mudah untuk mengakses pasar modal dengan biaya transaksi yang lebih rendah. Menurut Kasmir (2008:31) sebuah aset terdiri dari tiga kategori yang terkandung didalamnya yaitu aset lancar yang meliputi kas dan piutang. Aset tetap merupakan harta kekayaan milik perusahaan yang bersifat permanen. Aset lainnya merupakan aset yang tidak dapat dimasukan ke dalam kriteria aset lancar maupun aset tetap. Demikian juga dengan ukuran bank atau toal aset di perbankan khususnya BPR, manajemen bank dengan jumlah aset yang lebih tinggi cenderung berupaya untuk meningkatkan jumlah kecukupan modalnya (Mekonnen, 2015).

Sesuai dengan ketentuan Surat Edaran (SE OJK) Nomor 8/SEOJK.03/2016, BPR wajib menyampaikan laporan penggunaan aset kepada OJK dengan memperhatikan prinsip perhitungan ATMR, pos-pos aset yang tercatat dalam neraca BPR dikalikan dengan bobot risiko dalam bentuk persentase, dimana keseluruhan aset bank yang semakin tinggi dapat menyebabkan menurunnya rasio kecukupan modal bank. Penurunan CAR tersebut terjadi karena semakin tinggi aset yang dimiliki bank menyebabkan bank harus semakin meningkatkan ATMRnya, hal ini dipertegas dengan alasan lainnya yaitu apabila penyaluran kredit yang dilakukan bank cenderung diberikan kepada UMKM dan perorangan dengan risiko yang cukup tinggi menyebabkan nilai CAR akan semakin menurun. Berdasarkan 
penelitian sebelumnya, diketahui bahwa terdapat pengaruh yang positif dan signifikan antara ukuran bank atau size (total aset) terhadap CAR bank sebagaimana diungkapkan oleh Polat and Al-Khalaf (2014), Mekonnen (2015) serta Shingjergji and Hyseni (2015). Buyuksalvarci dan Abdioglu (2011) yang meneliti mengenai faktor-faktor yang mempengaruhi CAR bank di Turki mengungkapkan bahwa size (total aset) memiliki pengaruh yang tidak signifikan terhadap CAR. Wen (2007) dalam penelitiannya juga mengungkapkan bahwa ukuran bank tidak memiliki hubungan yang kuat dengan CAR.

Salah satu kegiatan yang dilakukan oleh bank adalah menyalurkan kredit. Penyaluran kredit ini akan membantu bank dalam memperoleh keuntungan dan laba yang akan meningkatkan kecukupan modal bank. Menurut Darmawi (2011:61) Loan to Deposit Ratio (LDR) adalah salah satu ukuran likuid dari konsep persediaan yang berbentuk rasio pinjaman terhadap deposit. LDR merupakan kegiatan bank dalam menyalurkan dana pihak ketiga pada kredit atau sejenis kredit. LDR akan menunjukkan kemampuan bank dalam menyalurkan dana pihak ketiga yang dihimpun. (Selamet Riyadi, 2006:165). Faktor ekspansi kredit yang ditunjukan dengan rasio LDR sangat penting oleh bank dalam menjalankan fungsi intermediasinya dengan tujuan untuk memperoleh laba yang didapat dari selisih penerimaan bunga kredit dengan beban bunga simpanan. Semakin tinggi LDR suatu bank menunjukkan kemampuannya dalam menyalurkan kembali dana yang diterima dalam bentuk kredit juga semakin baik, sehingga dapat mengurangi idle money dan opportunity cost. Berdasarkan penilaian tingkat kesehatan bank apabila semakin tinggi tingkat LDR bank menunjukkan bahwa bank tersebut memiliki 
kemampuan yang cukup aktif dalam menyalurkan kreditnya kepada masyarakat. Abusharba et al (2013) dalam penelitiannya menyatakan bahwa LDR memiliki pengaruh positif dan signifikan terhadap CAR. Septiani (2016) menunjukkan hasil LDR berpengaruh positif tidak signifikan. Penelitian lain yang dilakukan oleh Polat dan Al-Khalaf (2014) Nuviyanto dan Anggono (2014), Krisna (2008), Anjani (2014) menunjukkan hasil pengaruh negatif dan signifikan antara LDR dengan CAR.

Kredit yang disalurkan bank kepada nasabahnya, dapat menimbulkan risiko kredit yang memberikan dampak terhadap berjalannya kegiatan usaha perbankan. Ketika nasabah gagal membayar hutang atau kredit yang diterimanya pada saat jatuh tempo maka bank akan mengalami risiko kredit (Sudiyatno, 2013). Menurut Ismail (2009:226) Non Performing Loan (NPL) mencerminkan tingkat risiko kredit, dimana semakin tinggi NPL maka risiko kredit juga semakin tinggi. Dimana NPL terbagi menjadi Kredit Kurang Lancar, Diragukan, dan Macet. Peningkatan NPL akan berdampak pada meningkatnya tunggakan bunga kredit sehingga dapat menurunkan penerimaan pendapatan atas bunga kredit serta meningkatkan biaya operasional yang disebabkan karena pembentukan cadangan pembentukan penyisihan aktiva produktif (PPAP) yang harus dibuat oleh bank yang dapat berdampak pada kerugian yang dialami bank. Nilai NPL yang semakin kecil menyebabkan risiko kredit yang ditanggung bank juga akan semakin menurun. Nilai NPL yang ditetapkan oleh Bank Indonesia adalah dibawah 5 persen untuk dapat dikategorikan sebagai bank yang baik atau sehat. Penelitian yang dilakukan Shingjerji and Hyseni (2015) mengungkapkan bahwa terdapat pengaruh negatif 
yang signifikan antara NPL terhadap CAR bank. Hasil penelitian tersebut diperkuat dengan penelitian yang telah dilakukan oleh Margaretha (2011) Yuanjua and Shishun (2012), Satrigraha dan Purbawangsa (2014), Krisna (2008) dan Abusharba et al (2013). Penelitian berbeda diungkapkan oleh Anggono (2014), Raharjo et al (2014) dan Ahmad et al. (2008) yang mengungkapkan bahwa terdapat pengaruh positif signifikan antara NPL terhadap CAR bank. Wondifraw (2015) menyatakan bahwa NPL berpengaruh tidak signifikan terhadap CAR bank.

Perolehan pendapatan bunga bersih bank yang semakin tinggi dari penyaluran kredit yang dikelola oleh bank dapat menyebabkan laba bersih yang dihasilkan bank juga semakin meningkat. Peningkatkan jumlah laba bersih yang diperoleh tersebut menyebabkan semakin tingg pula jumlah modal bank. Menurut Riyadi (2006:21) Net Interest Margin (NIM) merupakan perbandingan antara presentase hasil bunga terhadap rata-rata aktiva produktif. NIM merupakan rasio yang digunakan untuk mengukur kinerja lini bisnis utama bank. Untuk dapat dikatakan sehat batas nilai NIM yang harus dimiliki bank adalah diatas 2 persen. Peningkatakan rasio ini menyebabkan semakin besarnya pendapatan bunga atas aktiva produktif yang diperoleh oleh bank sehingga masalah yang dihadapi bank akan semakin kecil (Kasmir, 2014). Penelitian yang dilakukan oleh Aktas et al (2015), Mili et al (2014), Romdhane (2012), serta Wondifraw (2015) menemukan hasil bahwa terdapat pengaruh yang positif signifikan antara NIM terhadap CAR. Hasil penelitian yang berbeda ditemukan oleh Mekonnen (2015) dan Wen (2007) yaitu terdapat pengaruh negatif yang signifikan antara NIM terhadao CAR, sementara Nuviyanto dan Anggono (2014), Raharjo et al (2014), Ahmad et al (2008), Buyuksalvarci dan 
Abdioglu (2011), dan Dreca (2013) dalam penelitiannya menyatakan bahwa NIM berpengaruh tidak signifikan terhadap CAR bank.

Berdasarkan penelitian sebelumnya di beberapa negara, mengungkapkan bahwa terdapat rasio-rasio keuangan bank yang dapat memengaruhi rasio kecukupan modal bank, yang diantaranya adalah Size/Ukuran Bank atau total aset suatu bank, rasio likuiditas yang biasa di perbankan di proksikan dengan Loan To Deposit Ratio (LDR), Non Performing Loan (NPL) yang mencerminkan risiko kredit, dan penilaian terhadap rasio rentabilitas menggunakan Net Interest Margin (NIM). Namun terdapat perbedaan mengenai jenis rasio-rasio keuangan yang berpengaruh signifikan terhadap kecukupan modal suatu bank di berbagai negara, sehingga penting untuk dilakukan penelitian kembalu mengenai faktor-faktor apa sajakah yang dapat memengaruhi rasio kecukupan modal bank

Menurut Hasibuan (2009) Bank didefinisikan sebagai sebuah badan usaha yang aset utamanya dalam bentuk keuangan (financial asset) yang tidak hanya bertujuan untuk mengejar keuntungan melainkan juga bermotifkan sosial. Suatu perusahaan setiap saat atau secara berkala perlu melakukan analisis terhadap kinerjanya, demikian pula dengan bank. Menurut Kasmir (2014) adapun jenis perbankan ini dapat dilihat dari segi fungsinya, antara lain 1) Bank umum menurut PBI Nomor 9 / 7 / PBI / 2007 merupakan bank yang dalam menjalankan kegiatan usahanya dilakukan dengan cara konvensional dan atau mengacu pada prinsip syariah yang dapat dijadikan sebagai lalu lintas pembayaran. 2) Bank Perkreditan Rakyat adalah bank yang dalam menjalankan kegiatan usahanya dilakukan dengan cara konvensional dan atau mengacu pada prinsip syariah namun kegiatan BPR jauh 
lebih sempit. Laporan keuangan akan melaporkan posisi perusahaan pada satu titik waktu tertentu maupun operasinya selama suatu periode di masa lalu.

Rivai et.al (2013) menyatakan pengukuran kinerja bank tidak hanya dilakukan berdasarkan ketentuan mengenai Tingkat Kesehatan Bank, namun tak jarang bank juga melengkapinya dengan analisis kinerja keuangan yang dilakukan dengan mengukur rasio - rasio keuangan bank. Menurut Kasmir (2014:46), Capital Adequacy Ratio (CAR) adalah perbandingan rasio antara rasio modal terhadap Aktiva Tertimbang Menurut Risiko dan sesuai ketentuan pemerintah. CAR merupakan rasio yang menunjukkan besarnya total aktiva yang dimiliki bank yang mengandung unsur risiko (penyertaan, kredit, tagihan pada bank lain, surat berharga) yang dibiayai dengan modal sendiri bank. Berdasarkan POJK Nomor 5/PJOK.03/2015 tentang Kewajiban Penyediaan Modal Minimum (KPMM) BPR mengatur bahwa BPR diwajibkan untuk menyediakan modal minimum yang dihitung dengan menggunakan rasio KPMM paling rendah sebesar $12 \%$ dari ATMR

Manajemen bank dengan jumlah aset yang lebih tinggi cenderung berupaya untuk meningkatkan jumlah kecukupan modalnya (Mekonnen, 2015). Jogiyanto (2007:282) menyatakan bahwa Ukuran aktiva digunakan untuk mengukur besarnya perusahaan, ukuran aktiva tersebut diukur sebagai logaritma dari total aktiva. Teori trade-off menyatakan bahwa apabila ukuran perusahaan meningkat, akan lebih mudah untuk mengakses pasar modal dengan biaya transaksi yang lebih rendah. Semakin besar ukuran perusahaan menyebabkan biaya produk yang dihasilkan perusahaan akan semakin rendah (Pratama, 2013). Ukuran suatu bank dapat 
diproksikan dengan keseluruhan aktiva yang dimilikinya. Apabila aktiva perusahaan yang merupakan sumber daya bagi perusahaan dimanfaatkan dengan baik maka tentu akan meningkatkan penghasilan (Putri, 2015). Ukuran bank diketahui berpengaruh signifikan terhadap CAR. Penelitian sebelumnya yang dilakukan Bateni et.al (2014) menyatakan terdapat pengaruh yang negatif antara ukuran bank terhadap CAR. Pengaruh negatif antara ukuran bank dengan CAR juga didukung oleh penelitian Al-Sabbagh (2004), Aktas et.al (2015) Dreca (2013), Mili et.al (2014), Shaddady dan Moore (2015), Raharjo et.al (2014), Ahmad et.al (2008). Hipotesis yang diajukan : Size/Ukuran Bank berpengaruh negatif signifikan terhadap CAR.

Menurut Darmawi (2011:61) LDR adalah salah satu ukuran likuid dari konsep persediaan yang berbentuk rasio pinjaman terhadap deposit. LDR mencerminkan kegiatan bank dalam menyalurkan kredit atau dana pihak ketiga. Rasio LDR yang semakin tinggi mencerminkan ekspasi kredit yang dilakukan oleh bank. Rasio LDR sangat penting bagi sebuah bank karena dengan rasio LDR yang tinggi bank dapat menjalankan fungsi sebagai intermediasi dan dapat mencapai tujuannya untuk menghasilkan laba dari selisih antara penerimaan bunga kredit terhadap beban bunga simpanan. Kemampuan perolehan laba yang semakin meningkat dapat didorong dari peningkatan kemampuan penyaluran kredit. Semakin tinggi LDR suatu bank menunjukkan kemampuannya dalam menyalurkan kembali dana yang diterima dalam bentuk kredit juga semakin baik, sehingga dapat mengurangi idle money dan opportunity cost. Abusharba et al (2013) dalam penelitiannya menyatakan bahwa LDR memiliki pengaruh positif dan signifikan 
terhadap CAR. Penelitian yang dilakukan oleh Polat dan Al-Khalaf (2014) Nuviyanto dan Anggono (2014), Raharjo et al (2014), Ahmad et al (2008) juga menunjukkan bahwa ada pengaruh positif dan signifikan antara LDR dengan CAR. Hipotesis yang diajukan : LDR berpengaruh positif signifikan terhadap CAR

Menurut Ismail (2009:224), Kredit bermasalah atau sering juga disebut dengan NPL dimana seluruh kewajiban nasabah tidak sanggup dibayarkan kepada bank yang bersangkutan seperti yang telah diperjanjikan. Menurut Siamat, (2001:174). Risiko kredit yang ditanggung bank dapat tercermin dari rasio NPL yang semakin meningkat. Rasio NPL yang semakin tinggi dapat menyebabkan risiko yang tunggakan bunga kredit juga akan semakin meningkat sehingga pendapatan bunga juga akan semakin menurun dan rasio CAR juga akan semakin menurun. NPL adalah rasio yang digunakan untuk mengukur kemampuan sebuah bank mengantisipasi kemungkinan terjadi risiko kegagalan pengembalian kredit oleh para nasabah. NPL mencerminkan risiko kredit, rasio NPL yang semakin rendah menunjukkan bahwa risiko kredit yang dihadapi bank akan semakin rendah. Hal tersebut tentu dapat berdampak pada laba yang semakin menurun yang mengakibatkan penurunan jumlah modal bank.

Penelitian yang dilakukan Shingjergji dan Hyseni (2015) mengungkapkan hasil bahwa NPL berpengaruh negatif dan signifikan terhadap CAR bank, yang didukung juga oleh penelitian yang dilakukan Yuanjua dan Shishun (2012), Satrigraha dan Purbawangsa (2014), Krisna (2008), Fitrianto (2006), Abusharba et.al (2013).

Hipotesis yang diajukan : NPL berpengaruh negatif signifikan terhadap CAR 
Menurut Kasmir (2008 : 297) Rasio NIM digunakan untuk mengukur tingkat efisiensi usaha dan rentabilitas atau profitabilitas yang dicapai bank yang bersangkutan. Penilaian terhadap rentabilitas menggunakan NIM. Berdasarkan Surat Edaran Bank Indonesia No.13/36/Intern tanggal 25 Oktober 2011 menyatakan rasio yang digunakan untuk mengukur kinerja lini bisnis utama bank diproksikan dengan NIM. Semakin tinggi NIM umumnya menyebabkan semakin baik rentabilitas bank. Semakin tinggi pendapatan bunga bersih yang diperoleh dari kredit maka semakin tinggi pula laba bersih yang diperoleh bank. Salah satu komponen pembentuk modal inti bank adalah laba, jumlah modal bank akan semakin tinggi, jika laba yang didapatkan bank makin tinggi. Berdasarkan penelitian sebelumnya yang dilakukan oleh Shitawati (2006), Hadinugroho dan Yudha, Aktas et.al (2015), Mili et.al (2014), Romdhane (2012), serta Wondifraw (2015) menyatakan bahwa NIM berpengaruh positif dan signifikan terhadap CAR. Hipotesis yang diajukan : NIM berpengaruh positif signifikan terhadap CAR

Berdasarkan kajian pustaka yang telah dipaparkan pada sebelumnya, baik dari aspek teoritis maupun empiris, berbagai rasio keuangan bank telah digunakan untuk menjelaskan beberapa faktor yang mempengaruhi kecukupan modal bank, maka dapat disusun kerangka pemikiran sebagai berikut:

\section{Gambar 1. Kerangka Berpikir}

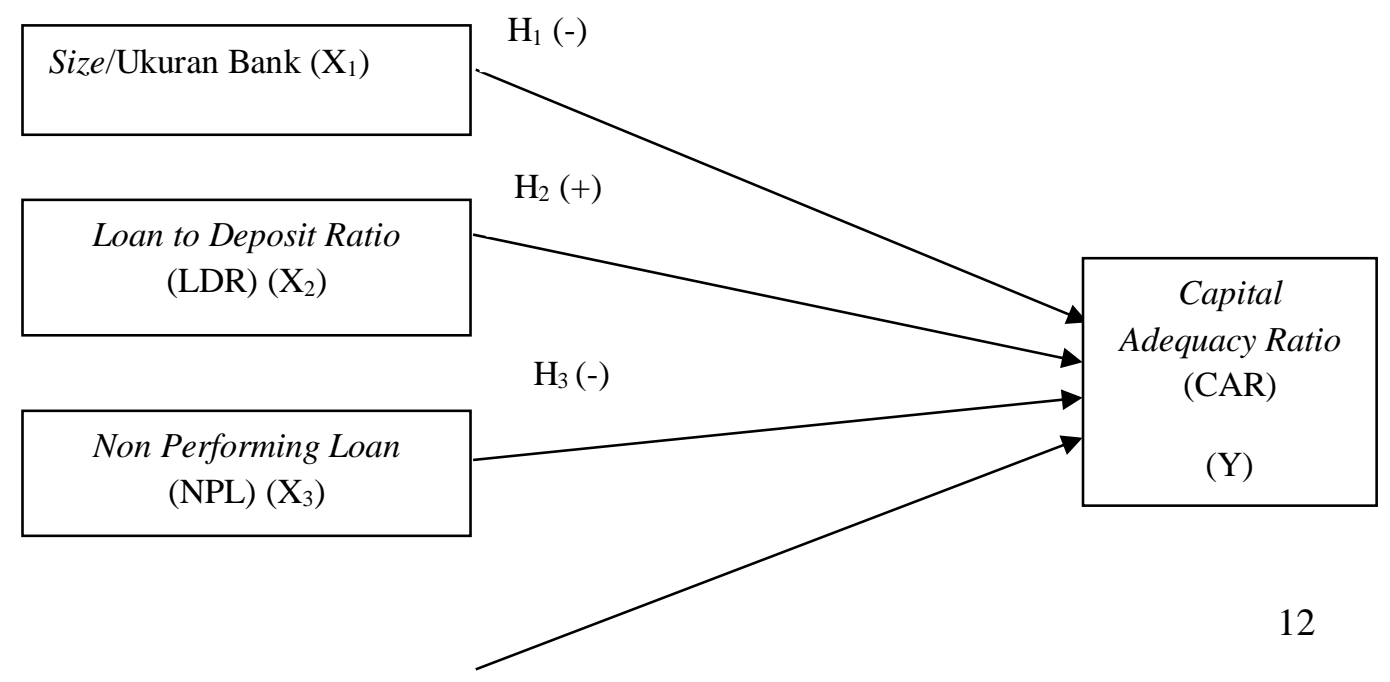




$$
\mathrm{H}_{4}(+)
$$

Net Interest Margin (NIM)

$\left(\mathrm{X}_{4}\right)$

Sumber: Data diolah, 2017

\section{METODE PENELITIAN}

Pendekatan dalam penelitian ini adalah berbentuk asosiatif. Penelitian asosiatif merupakan penelitian yang menjelaskan hubungan antara dua variabel atau lebih (Sugiyono, 2012). Pada penelitian ini menggunakan empat (4) variabel bebas yaitu : Size, LDR, NPL dan NIM digunakan untuk mengetahui pengaruhnya terhadap variabel terikat yaitu CAR.

Penelitian dilakukan pada BPR di Provinsi Bali dengan melakukan download data keuangan 137 BPR di Bali, melalui aplikasi Sistem Pengawasan (SIMWAS) BPR Periode (2015-2016). Laporan keuangan BPR diperoleh dari laporan keuangan publikasi triwulan BPR yang di-download melalui website OJK (www.ojk.go.id). Obyek pada penelitian ini adalah variabel yang mempengaruhi CAR pada BPR di Provinsi Bali periode (2015-2016).

Jenis data yang digunakan dalam penelitian ini antara lain data kuantitatif, data yang dinyatakan dalam bentuk angka-angka, yaitu data-data keuangan BPR di Provinsi Bali meliputi rasio keuangan serta laporan keuangan periode (2015-2016) yang meliputi neraca dan laporan laba rugi. Data keuangan meliputi data mengenai Size/Ukuran Bank dan rasio LDR, NPL dan NIM. Data kualitatif, data yang tidak dapat dinyatakan dalam bentuk angka-angka atau satuan tertentu seperti penjelasan 
atas Peraturan Otoritas Jasa Keuangan (POJK) tentang Kewajiban Penyediaan Modal Minimum bagi BPR.

Sumber data yang dipergunakan adalah sumber sekunder. Sumber sekunder dalam penelitian ini antara lain rasio keuangan dan laporan keuangan BPR di Provinsi Bali periode (2015-2016) yang diperoleh dari aplikasi SIMWAS BPR di Provinsi Bali. Laporan keuangan BPR diperoleh dari laporan keuangan publikasi triwulanan BPR yang di-download melalui website OJK (www.ojk.go.id)

Variabel independen dalam penelitian ini terdiri dari 4 (empat) variabel antara lain Size/Ukuran bank, LDR, NPL dan NIM. Variabel dependen dalam penelitian ini adalah CAR yang merupakan rasio kinerja bank untuk mengukur kecukupan modal yang dimiliki bank untuk menunjang aktiva yang mengandung atau menghasilkan risiko.

Dalam penelitian ini perhitungan size atau ukuran bank diproksikan dengan natural logaritma total aset yang dimiliki 137 BPR yang berkantor pusat di Provinsi Bali periode (2015-2016). Penentuan nilai ukuran bank dalam penelitian ini dilakukan dengan menggunakan rumus sebagai berikut (Riyanto, 2008:313).

Ukuran Perusahaan $($ Size $)=$ LnTotalAset

Loan to Deposit Ratio merupakan perbandingan antara jumlah kredit yang disalurkan terhadap keseluruhan dana yang diterima oleh BPR yang berkantor pusat di Provinsi Bali periode (2015-2016). Berdasarkan Surat Keputusan Direksi Bank Indonesia No.30/12/KEP/DIR tentang Tata Cara Penilaian Tingkat Kesehatan BPR, likuiditas BPR dinilai sehat apabila LDR-nya kurang dari 94,75\%. Besarnya LDR dihitung dengan rumus : Veithzal Rivai (2006:156) 


$$
\text { LDR }=\frac{\text { Jumlah Kredit }}{\text { Dana Pihak Ketiga }} \quad \times 100 \%
$$

Perhitungan Non Performing Loan dilakukan dengan membandingkan keseluruhan kredit bermasalah yang terdiri atas kredit kurang lancar, diragukan dan macet terhadap keseluruhan kredit yang disalurkan oleh BPR yang berkantor pusat di Provinsi Bali periode (2015-2016). NPL dapat dirumuskan sebagai berikut (Ismail, 2009: 228).

$\mathrm{NPL}=$ kredit bermasalah $\quad \mathrm{x} 100 \%$

kredit yang diberikan

Net Interest Margin diperoleh dari perbandingan antara pendapatan bunga bersih terhadap rata - rata total aktiva produktif dari 137 BPR yang berkantor pusat di Provinsi Bali periode (2015-2016). Formula perhitungannya adalah sebagai berikut. (Masyhud Ali, 2004).

$$
\mathrm{NIM}=\frac{\text { Pendapatan Bunga Bersih } \quad \mathrm{x}}{\text { Rata-rata Aktiva Produktif }} \quad 100 \%
$$

Capital Adequacy Ratio adalah rasio kinerja bank untuk mengukur seluruh aktiva yang mengandung atau menghasilkan risiko dan ikut dibiayai oleh modal yang dimiliki bank. Besarnya CAR suatu bank dapat dihitung dengan rumus berikut. (Lukman Dendawijaya, 2009:121)

$$
\text { CAR }=\frac{\text { Modal }}{\text { ATMR }}
$$$$
\mathrm{x} 100 \%
$$

Populasi dalam penelitian ini adalah seluruh BPR konvensional yang berkantor pusat di wilayah kerja Provinsi Bali. Jumlah populasi dalam penelitian 
ini adalah 137 BPR. Teknik pengambilan sampel yang digunakan adalah metode sensus, karena sampel yang diolah diambil dari semua anggota populasi. Metode pengumpulan data dalam penelitian ini adalah metode observasi non participant.

Teknik analisis data yang digunakan dalam penelitian ini adalah teknik analisis regresi berganda, dalam penelitian ini digunakan untuk mengetahui pengaruh dari variabel bebas terhadap variabel terikat. Dalam hal ini yang menjadi variabel independen adalah Size $\left(\mathrm{X}_{1}\right)$, LDR $\left(\mathrm{X}_{2}\right)$ dan NPL $\left(\mathrm{X}_{3}\right)$ dan NIM $\left(\mathrm{X}_{4}\right)$ terhadap CAR (Y) pada BPR di Bali periode (2015-2016). Formulasi persamaan regresi linier berganda dirumuskan sebagai berikut (Nata Wirawan, 2002:293) :

$Y=\alpha+\beta_{1} X_{1}+\beta_{2} X_{2}+\beta_{3} X_{3}+\beta_{4} X_{4}+e$

Keterangan :

$\begin{array}{lll}\mathrm{Y} & : & \text { Capital Adequacy Ratio (CAR) } \\ \alpha & : & \text { Bilangan Konstanta } \\ \beta_{1}-\beta_{4} & : & \text { Koefisien Regresi dari masing-masing variabel independen } \\ \mathrm{X}_{1} & : & \text { Size/Ukuran Bank } \\ \mathrm{X}_{2} & : & \text { Loan to Deposit Ratio (LDR) } \\ \mathrm{X}_{3} & : & \text { Non Performing Loan (NPL) } \\ \mathrm{X}_{4} & : & \text { Net Interest Margin (NIM) } \\ \mathrm{e} & : & \text { Error }\end{array}$

\section{HASIL DAN PEMBAHASAN}

Penelitian ini dilakukan pada Bank Perkreditan Rakyat (BPR) di Provinsi Bali Periode 2015-2016. Jumlah BPR yang berkantor pusat di Provinsi Bali adalah sebanyak 137 bank. Dengan menggunakan metode sensus, karena sampel yang diolah diambil dari semua anggota populasi. Jumlah sampel yangdigunakan dalam penelitian ini adalah sebanyak 137 BPR di Provinsi Bali. Pengujian deskriptif 
dilakukan dengan tujuan untuk mengetahui gambaran umum mengenai sampel penelitian. Statistik deskriptif memberikan gambaran tentang jumlah sampel pada penelitian, nilai minimum, nilai maksimum, nilai rata-rata (mean), dan standar deviasi dari masinh-masing variabel. Standar deviasi berfungsi ntuk mengetahui besarnya penyimpangan dari nilai rata - rata data. Analisis deskriptif dalam penelitian ini terlihat pada tabel berikut.

Tabel 2.

Statistik Deskriptif

\begin{tabular}{cccccc}
\hline & $\mathrm{N}$ & Minimum & Maximum & Mean & Std. Deviation \\
\hline CAR & 137 & 11.35 & 37.92 & 22.1551 & 5.97231 \\
SIZE & 137 & 15.96 & 21.45 & 17.736 & 0.71256 \\
LDR & 137 & 65.71 & 98.17 & 82.662 & 5.43294 \\
NPL & 137 & 0.92 & 18.85 & 6.6242 & 3.29738 \\
NIM & 137 & 3.59 & 46.58 & 17.6027 & 50.68455 \\
Valid N & & & & & \\
(listwise) & 137 & - & - & - & - \\
\hline
\end{tabular}

Sumber: data sekunder diolah, 2017

Berdasarkan hasil pengujian statistik deskriptif diperoleh nilai CAR minimum dari BPR di Provinsi Bali sebesar 11,35 sedangkan nilai maksimum CAR adalah sebesar 37,92. Nilai rata-rata CAR adalah sebesar 22,1551. Hal ini menunjukkan bahwa setiap tahunnya selama periode 2015-2016 rata-rata CAR mengalami peningkatan karena CAR menunjukkan nilai yang positif. Standar deviasi CAR adalah sebesar 5,97231 atau 597,231 persen artinya terjadi penyimpangan nilai CAR terhadap nilai rata-rata CAR sebesar 5,97231 atau 597,231 persen.

Nilai minimum Size adalah sebesar 15,96 sedangkan nilai maksimum Size sebesar 21,4. Nilai rata-rata Size sebesar 17,7360. Standar deviasi dari Size adalah 
sebesar 0,71256 atau 71,256 persen Hal ini berarti telah terjadi penyimpangan nilai Size terhadap nilai rata-rata Size sebesar 0,71256 atau 71,256 persen

Nilai minimum LDR adalah sebesar 65,71 sedangkan nilai maksimum LDR sebesar 98,17. Nilai rata-rata LDR sebesar 82,662. Standar deviasi dari LDR adalah sebesar 5,43294 atau 543,294 persen Hal ini berarti telah terjadi penyimpangan nilai LDR terhadap nilai rata-rata LDR sebesar 5,43294 atau 543,294 persen.

Nilai minimum NPL adalah sebesar 0,92 sedangkan nilai maksimum NPL sebesar 18,85. Nilai rata-rata NPL sebesar 6,6242. Standar deviasi dari LDR adalah sebesar 3,29738 atau 329,738 persen Hal ini berarti telah terjadi penyimpangan nilai NPL terhadap nilai rata-rata NPL sebesar 3,29738 atau 329,738 persen

Nilai minimum NIM adalah sebesar 3,59 sedangkan nilai maksimum NIM sebesar 46.58. Nilai rata-rata NIM sebesar 17,6027. Standar deviasi dari NIM adalah sebesar 50,68455 atau 5068,455 persen Hal ini berarti telah terjadi penyimpangan nilai NPL terhadap nilai rata-rata NIM sebesar 50,68455 atau 5068,455 persen.

Tabel 3.

Hasil Uji Normalitas

\begin{tabular}{lr}
\hline & Residual \\
\hline $\mathrm{N}$ & 137 \\
Kolmogrov-Smirnov Z & 1.19 \\
Asymp. Sig. (2-tailed) & .118 \\
\hline Sumber $:$ data sekunder diolah, 2017
\end{tabular}

Berdasarkan tabel 3 hasil uji normalitas dapat dilihat bahwa nilai Asymp. Sig. (2-tailed) sebesar 0,118. Asymp. Sig. (2-tailed) sebesar 0,118> level of 
significant $(\alpha=0,05)$ ini berarti seluruh data telah berdistribusi normal dan model ini dapat digunakan untuk melakukan analisis lebih lanjut.

Tabel 4.

Hasil Uji Multikolinieritas

Coefficients $^{\mathrm{a}}$

\begin{tabular}{clcc}
\hline \multirow{2}{*}{ Model } & & \multicolumn{2}{c}{ Collinearity Statistic } \\
\cline { 3 - 4 } 1 & (Constant) & Tollerance & VIF \\
& SIZE & 0.739 & 1.354 \\
& LDR & 0.899 & 1.112 \\
& NPL & 0.961 & 1.04 \\
& NIM & 0.79 & 1.266 \\
\hline
\end{tabular}

a. Dependent Variable: CAR

Sumber: data sekunder diolah, 2017

Dari hasil tabel 4 menunjukkan bahwa nilai Variance Inflation Factor (VIF)

dari keempat variabel tidak ada yang lebih besar dari 10, maka dapat dapat dikatakan tidak terjadi multikolinearitas dari model regresi. Model regresi linier yang baik adalah yang terbebas dari adanya multikolinieritas. Dengan demikian, model diatas telah terbebas dari adanya multikolnieritas.

Tabel 5.

Hasil Uji Heteroskedastisitas

\begin{tabular}{crc}
\hline Variabel Bebas & T Statistik & Sig. \\
\hline SIZE & -1.398 & 0.165 \\
LDR & 0.311 & 0.756 \\
NPL & -0.418 & 0.677 \\
NIM & 1.937 & 0.055 \\
\hline
\end{tabular}

a. Dependent Variable: Absres

Sumber : data sekunder diolah, 2017

Berdasarkan Tabel 5 disajikan hasil olahan data uji heteroskedastisitas yang menunjukkan nilai signifikansi lebih besar daripada 0,05 berarti bahwa seluruh variabel bebas tidak berpengaruh signifikan terhadap residual kuadrat. Sehingga 
dapat dikatakan model regresi yang digunakan bebas dari adanya gejala heteroskedastisitas.

Tabel 6.

Hasil Analisis Regresi Linier Berganda

\begin{tabular}{rlrrrr}
\hline Model & & B Unstandardized & Beta Standardized & t statistik & \multicolumn{1}{c}{ Sig. } \\
\hline \multirow{2}{*}{1} & (Constant) & 99.075 & & 6.468 & 0 \\
& SIZE & -3.653 & -0.436 & -4.905 & 0 \\
& LDR & 0.349 & 0.193 & 2.396 & 0.018 \\
& NPL & -0.179 & -0.163 & -2.095 & 0.038 \\
& NIM & 0.021 & 0.182 & 2.123 & 0.036 \\
\hline
\end{tabular}

a. Dependent Variable: CAR

Sumber: Data sekunder diolah, 2017

Berdasarkan tabel 6 dapat dirumuskan persamaan regresi linier berganda sebagai berikut:

$$
\mathrm{Y}=99.075-3,653\left(\mathrm{X}_{1}\right)+0,349\left(\mathrm{X}_{2}\right)-0,179\left(\mathrm{X}_{3}\right)+0,021\left(\mathrm{X}_{4}\right)
$$

Nilai beta dari Size yang bertanda negatif yaitu sebesar -3,653 artinya bahwa setiap variabel Size meningkat sebesar 1 persen, maka CAR akan mengalami penurunan sebesar 3,653 persen dengan asumsi variabel lain konstan.

Nilai beta dari LDR yang bertanda positif yaitu sebesar 0,349 artinya bahwa setiap variabel LDR meningkat sebesar 1 persen, maka CAR akan mengalami peningkatan sebesar 0,349 persen dengan asumsi variabel lain konstan.

Nilai beta dari NPL yang bertanda negative yaitu sebesar -0,179 artinya bahwa setiap variabel NPL meningkat sebesar 1 persen, maka CAR akan mengalami penurunan sebesar 0,179 persen dengan asumsi variabel lain konstan.

Nilai beta dari NIM yang bertanda positif yaitu sebesar 0,021 artinya bahwa setiap variabel NIM meningkat sebesar 1 persen, maka CAR akan mengalami peningkatan sebesar 0,021 persen dengan asumsi variabel lain konstan. 
Tabel 7.

Hasil Uji Kelayakan Model

\begin{tabular}{llccc}
\multicolumn{5}{c}{ ANOVA $^{\mathbf{b}}$} \\
\hline \multirow{2}{*}{ Model } & & $\begin{array}{l}\text { Sum Of } \\
\text { Square }\end{array}$ & F & \multirow{2}{*}{ Sig. } \\
\hline \multirow{2}{*}{1} & Regression & 1116.471 & 9.866 & $.000 \mathrm{a}$ \\
& Residual & 3734.442 & & \\
& Total & 4850.913 & & \\
\hline
\end{tabular}

a. Predictors: (Constant), NIM, NPL, LDR, SIZE

b. Dependent Variable: CAR

Sumber: Data sekunder diolah, 2017

Berdasarkan tabel 7 dapat dilihat hasil Uji $\mathrm{F}$ menunjukkan bahwa nilai $\mathrm{F}$ hitung 9,866 dengan signifikansi F sebesar 0,000 yang lebih kecil dari $\alpha=0,05$, ini berarti model yang digunakan dalam penelitian ini layak untuk digunakan.

Tabel 8.

Hasil Uji Koefisien Determinasi Model Summary ${ }^{\text {b }}$

\begin{tabular}{ccccc}
\hline Model & $\mathrm{R}$ & R Square & $\begin{array}{c}\text { Adjusted R } \\
\text { Square }\end{array}$ & $\begin{array}{c}\text { Std. Error of the } \\
\text { Estimate }\end{array}$ \\
\hline 1 & $.480^{\mathrm{a}}$ & 0.23 & 0.207 & 5.31895 \\
\hline
\end{tabular}

a. Predictors: (Constant), NIM, NPL, LDR, SIZE

Sumber: Data sekunder diolah, 2017

Berdasarkan tabel 8 dapat dilihat nilai dari $R$ Square adalah 0,230 atau 23\% artinya besarnya kemampuan variasi Size, LDR, NPL dan NIM dapat menjelaskan variabel CAR sebesar 23\% sedangkan sisanya $77 \%$ dijelaskan oleh faktor lain yang tidak termasuk dalam model.

Hipotesis pertama menyatakan Size berpengaruh ngatif signifikan terhadap CAR. Berdasarkan hasil penelitian pada Bank Perkreditan Rakyat (BPR) di Provinsi Bali Periode 2015-2016 menunjukkan bahwa, Size berpengaruh negatif 
signifikan terhadap CAR bank. Apabila Size atau total aset mengalami peningkatan artinya bank akan cenderung menempatkan dananya pada aktiva-aktiva yang produktif, pada aktiva-aktiva produktif terkandung risiko yang besar, sehingga semakin besar dana pada aktiva produktif maka ATMR bank akan semakin besar, sehingga terjadi penurunan pada kecukupan modalnya dan berdampak pada CAR yang akan menurun. Hasil penelitian ini didukung oleh hasil penelitian sebelumnya yang dilakukan oleh Aktas et.al (2015), Bateni et.al (2014), Dreca (2013), Mili et.al (2014) yang mendapatkan hasil bahwa size/ukuran bank berpengaruh negatif dan signifikan terhadap CAR bank.

Hipotesis kedua menyatakan LDR berpengaruh positif signifikan terhadap CAR. Berdasarkan hasil penelitian ini, didapatkan hasil LDR berpengaruh positif signifikan terhadap CAR pada BPR di Provinsi Bali Periode 2015-2016. LDR mencerminkan kemampuan bank dalam menyalurkan dana pihak ketiga, dan jika tidak tersalur akan timbul idle money yang akan mengakibatkan opportunity cost. Semakin tinggi tingkat kredit yang disalurkan bank maka peluang bank dalam memperolehan keuntungan akan semakin tinggi. Pendapatan bunga yang diperoleh dari pembayaran kredit nasabah akan meningkatkan keuntungan atau laba bank, sehingga modal bank juga akan meningkat. Hasil penelitian ini didukung oleh hasil penelitian sebelumnya yang dilakukan oleh Bukian (2016), Abusharba (2013), Ahmad et al (2014) bahwa LDR berpengaruh positif dan signifikan terhadap CAR.

Hipotesis ketiga menyatakan NPL berpengaruh negatif signifikan terhadap CAR. Hasil penelitian ini menunjukkan bahwa NPL berpengaruh negatif signifikan terhadap CAR pada BPR di Provinsi Bali Periode 2015-2016. Besarnya 
resiko kredit bermasalah akan menyebabkan bank harus membentuk cadangan pembentukan (PPAP), pembentukan cadangan penghapusan kredit ini akan berdampak penurunan laba pada bank dan juga penurunan jumlah modal bank. Hasil penelitian ini didukung oleh hasil penelitian sebelumnya yang dilakukan oleh Yuanjua dan Shishun (2012), Satrigraha dan Purbawangsa (2014), Maheswari (2014), Krisna (2008), Abusharba et.al (2013), Shingjerji and Hyseni (2015) bahwa NPL berpengaruh negatif dan signifikan terhadap CAR bank.

Hipotesis keempat menyatakan NIM berpengaruh positif signifikan terhadap CAR. Hasil penelitian ini menunjukkan bahwa NIM berpengaruh positif signifikan terhadap CAR pada BPR di Provinsi Bali Periode 205-2016. Nilai NIM yang semakin tinggi cenderung menyebabkan rentabilitas sebuah bank menjadi semakin baik. Apabila pendapatan bunga bersih sebuah bank semakin tinggi yang mencerminkan kemampuan menyalurkan kredit sebuah bank maka akan menyebabkan laba bersih yang diterima juga akan semakin meningkat. Jika laba yang didapatkan tinggi, maka modal bank juga akan semakin tinggi dan CAR bank akan mengalami peningkatan, mengingat laba merupakan satu dari komponen modal. Hasil penelitian ini didukung dengan penelitian yang pernah dilakukan oleh Shitawati (2006), Hadinugroho dan Yudha, Aktas et.al (2015), Mili et.al (2014), Romdhane (2012), serta Wondifraw (2015).

\section{SIMPULAN DAN SARAN}

Berdasarkan hasil analisis data dan pembahasan penelitian yang telah diuraikan, dapat ditarik kesimpulan sebagai berikut: Size/Ukuran Bank berpengaruh 
negatif signifikan terhadap CAR. LDR berpengaruh positif signifikan terhadap profitabilitas. NPL berpengaruh negatif signifikan terhadap CAR. NIM berpengaruh positif signifikan terhadap CAR. Besarnya pengaruh keempat variabel independen tersebut dapat diketahui dari nilai koefisien determinasi sebesar 23 persen dan sisanya 77 persen dipengaruhi oleh factor lain yang tidak dimasukkan dalam model.

Berdasarkan hasil penelitian dan kesimpulan, BPR di Provinsi Bali dalam usaha mencapai kecukupan modal yang optimal perlu memperhatikan variabelvariabel Size/Ukuran Bank, Loan to Deposit Ratio (LDR), Non Performing Loan (NPL), dan Net Interest Margin (NIM) karena secara simultan mempunyai pengaruh yang signifikan terhadap rasio kecukupan modal. BPR hendaknya lebih memperhatikan rasio-rasio yang memiliki pengaruh negatif terhadap kecukupan modal bank, apabila komponen tersebut dapat dikelola dengan baik maka dapat mengoptimalkan kecukupan modal bank. Bagi peneliti selanjutnya disarankan agar tidak hanya memakai variabel Size, LDR, NPL dan NIM untuk menganalisis pengaruhnya terhadap CAR bank. Hal ini dikarenakan masih ada faftor-faktor lain yang dapat mempengaruhi rasio kecukupan modal suatu bank. Selain itu, peneliti selanjutnya disarankan untuk menambah tahun pengamatan sehingga hasil yang diperoleh dapat dijadikan dasar pengambilan keputusan bagi pihak-pihak yang membutuhkan.

\section{REFRENSI}

Abusharba, Mohammed. T, Iwan Triyuwono, Munawar Ismail dan Aulia F. 
Rahman. 2013. Determinants of Capital Adequacy Ratio (CAR) in Indonesian Islamic Commercial Banks. Global Review of Accounting and Finance, 4(1): 159-170.

Ahmad, Rubi., M. Ariff., Skully, Michael J. 2008. The Determinants of Bank Capital Ratios in a Developing Economy. Asia-Pacific Finan Markets (1): 255-272.

Aktas, Rafet. Acikalin, Suleyman. Bakin, Bilge. Celik, Gokhan. 2015. The Determinants of Banks' Capital Adequacy Ratio : Some Evidence from South Eastern European Countries. Journal Economics and Behavioral Studies, 7 (1), 79-88.

Ali, Masyhud, (2004). Asset Liability Management: Menyiasati Risiko Pasar dan Risiko Operasional dalam Perbankan. Jakarta: PT. Elex Media Komputindo.

Al-Sabbagh, Noor Mohammad. 2004. Determinants of Capital Adequacy Ratio in Jordanian Banks, Thesis, The Degree of Master of (Banking \& Finance Sciences) at Yarmouk University.

Anjani, Dewa Ayu dan Purnawati, Ni Ketut 2015. Pengaruh Non Performing Loan (NPL), Likuiditas dan Rentabilitas Terhadap Rasio Kecukupan Modal Sektor Perbankan BEI. E-Jurnal Manajemen Unud. Vol. 3, No. 4. 11401155

Asnawi, Said Kelana dan Chandra Wijaya. (2005). Riset Keuangan : Pengujian Pengujian Empiris. Jakarta: Gramedia Pustaka Utama.

Brigham, Eugene F., Daves, Phillips R. 2010. Intermediate Financial Management, $10^{\text {th }}$ Edition. New York : South Western Thomson Corporation.

Brigham, Eugene F., Houston, Joel F. 2011. Fundamental of Financial Management, $13^{\text {th }}$ Edition. New York : Thomson South Western Mc Graw Hill International.

Bukian, Winda Parascintya dan Sudiartha, Gede Mertha 2016. Pengaruh Kualitas Aset, Likuiditas, Rentabilitas Dan Efisiensi Operasional Terhadap Rasio Kecukupan Modal. E-Jurnal Manajemen Unud. Vol. 5, No. 2, 2016: 1189-1221

Buyuksalvarci, Ahmet and Abdioglu, Hasan. 2011. Determinants of Capital Adequacy Ratio in Turkish Banks : A Panel Data Analysis. African Journal of Business Management, 5 (27),11199-11209.

Darmawi, Herman. 2011. Manajemen Perbankan. Jakarta : Bumi Aksara 
Dendawijaya, Lukman. (2009). Manajemen Perbankan. Ghalia Indonesia, Jakarta.

Dreca, Nada. 2013. Determinants of Capital Adequacy Ratio in Selected Bosnian Banks. Dumlupınar Üniversitesi Sosyal Bilimler Dergisi EYI

Fitrianto, Hendra dan Wisnu Mawardi. 2006. Analisis Pengaruh Kualitas Aset, Likuiditas, Rentabilitas dan Efisiensi Terhadap Rasio Kecukupan Modal Perbankan yang Terdaftar di Bursa Efek Jakarta. Jurnal Studi Manajemen dan Organisasi, 3 (1): 1-11.

Ghozali, Imam. (2009). Ekonometrika: Teori, Konsep, dan Aplikasi dengan SPSS 17. Badan Penerbit Universitas Diponegoro, Semarang.

Ghozali, Imam. (2012). Aplikasi Analisis Multivariet Dengan Program SPSS. Semarang

Gujarati, Damodar, 2003, Ekonometrika Dasar, Terjemahan: Sumarno Zain, Jakarta: Erlangga.

Hadinugroho, Listijowati dan Yudha, Haris Sakti. 2012. Analisis Faktor-Faktor yang Mempengaruhi Capital Adequacy Ratio Pada Bank Umum Indonesia. Jurnal Institut Perbanas 7 (4), pp: 1-12.

Hartono, Jogiyanto. (2007). Metodologi Penelitian Bisnis: Salah Kaprah dan Pengalaman-Pengalaman. Edisi 2007. BPFE. Yogyakarta

Ismail. (2009). Akuntansi Bank: Teori dan Aplikasi dalam Rupiah. Jakarta: Kencana 2011

Kasmir. (2012). Analisis Laporan Keuangan. Jakarta: Rajawali Pers

Kasmir. (2014). Bank dan Lembaga Keuangan Lainnya. Edisi Revisi, Cetakan keempatbelas, PT. RajaGrafindo Persada, Jakarta.

Kosmidou, Kyriaki \& Zopoundis, Constantin. 2008. Measurement Of Bank Performance In Greece. South-Eastern Europe Journal of Economics, 1 (1), 79-95

Krisna, Yansen. 2008. Faktor-Faktor yang Mempengaruhi Capital Adequacy Ratio (Studi Pada Bank-Bank Umum di Indonesia Periode 2003-2006), Tesis, Program Studi Magister Manajemen, Program Pasca Sarjana Universitas Diponegoro

Kuncoro, Mudrajad dan Suhardjono.(2002). Manajemen Perbankan Teori dan Aplikasi.Edisi Pertama. BPFE Yogyakarta, Yogyakarta 
Maheswari, Kadek Indah dan I Made Surya Negara Sudirman. 2014. Pengaruh NPL Terhadap ROA dengan Mediasi CAR dan BOPO Pada Perbankan Indonesia. E-Jurnal Manajemen Universitas Udayana, 3 (4): 1119-1139.

Margaretha, Farah dan Diana Setiyaningrum. 2011. Pengaruh Resiko, Kualitas Manajemen, Ukuran dan Likuiditas Bank terhadap Capital Adequacy Ratio Bank-Bank yang Terdaftar di Bursa Efek Indonesia. Jurnal Akuntansi dan Keuangan, 13 (1), pp: 47-56.

Mehdi, Mili,. Sahut, Jean-Michel., and Trimeche, Hatem. 2014. Determinants of the Capital Adequacy Ratio of a Foreign Bank's Subsidiaries: The Role of the Interbank Market and Regulation of Multinational Banks. Working Paper, 2014-366

Mekonnen, Yonas. 2015. Determinants of Capital Adequacy of Ethiopia Commercial Banks. European Scientific Journal, 11 (25): 315-331

Nata Wirawan, I Gusti Putu. (2002). Cara Mudah Memahami Statistik 2 (Statistik Inferensia) untuk ekonomi dan bisnis. Edisi Kedua. Denpasar: Keraras Emas

Nuviyanti dan Anggono, Achmad Herlanto. 2014. Determinants of Capital Adequacy Ratio (CAR) in 19 Commercial Banks (Case Study : Period 2008-2013). Journal of Business And Management, 3 (7), 752-764.

Pastory, Dickson dan Marobhe Mutaju. 2013. The Influence of Capital Adequacy on Asset Quality Position of Banks in Tanzania. International Journal of Economics and Finance, 5 (2), 179-194.

Peraturan Bank Indonesia (PBI) No.8/18/PBI/2006 tentang Kewajiban Penyediaan Modal Minimum Bank Perkreditan Rakyat

Peraturan Otoritas Jasa Keuangan (POJK) Nomor 5/POJK.03/2015 tentang Kewajiban Penyediaan Modal Minimum Bank Perkreditan Rakyat

Polat, Ali, and Al-khalaf, Hassan. 2014. What Determines Capital Adequacy in the Banking System of Kingdom of Saudi Arabia? A Panel Data Analysis on Tadawul Banks. Journal of Applied Finance \& Banking, 4 (5), 27-43.

Prasetyantoko, A. (2008). Bencana Finansial, Stabilitas Sebagai Barang Publik. Jakarta: Kompas Media Nusantara.

Pratama, Nur Edwin. 2013. Pengaruh Equity Multiplier, Working Capital Turnover, dan Size Terhadap Return on Equity Pada Perusahaan Aneka Industri yang 
Terdaftar di BEI Periode 2009-2012. Jurnal Universitas Maritim Raja Ali Haji, Tanjungpinang

Purbawangsa, Ida Bagus Anom dan Satrigraha, Ni Putu Tika Andriani dan. 2014. Pengaruh Profitabilitas dan Risiko Kredit Terhadap Capital Adequacy Ratio dan Harga Saham. E-Jurnal Manajemen Universitas Udayana, 3 (3): 595-608

Putri, Auliya Rasdiana,. 2015. Analisis Kinerja Keuangan Pada Bank Umum Konvensional dan Bank Umum Syariah di Indonesia. Jurnal Ilmiah Fakultas Ekonomi dan Bisnis, Universitas Brawijaya Malang Vol. 3 (2)

Raharjo, Pamuji Gesang,. Hakim, Dedi Budiman,. Manurung, Adler Haymans,. Maulana ,Tubagus Nur Ahmad. 2014. Determinant of Capital Ratio : A Panel Data Analysis on State-Owned Banks in Indonesia. Buletin Ekonomi Moneter dan Perbankan, 16 (4): 396-414

Rivai, Veitzhal., Basir, Sofyan., Sudarto, Sarwono,. Veithzal, Arifiandy Permata. 2013. Commercial Bank Management : Manajemen Perbankan dari Teori ke Praktik. Edisi ke-2. Jakarta : PT Raja Grafindo Persada

Romdhane, Mohamed. 2012. The Determinants of Banks' Capital Ratio in Developing Countries: Empirical Evidence from Tunisia. Research Journal of Finance and Accounting, 3 (1): 35-46

Santoso, Singgih. 2015. Menguasai Statistik Multivariat : Konsep Dasar dan Aplikasi dengan SPSS. Jakarta : PT Elex Media Komputindo

Sekaran, Uma (2011). Research Methods for business Edisi I and 2. Jakarta: Salemba Empat.

Septiani, Rita dan Lestari, Putu Vivi. 2016. Pengaruh NPL Dan LDR Terhadap Profitabilitas Dengan CAR Sebagai Variabel Mediasi Pada PT. BPR Pasarraya. E-Jurnal Manajemen Unud, Vol. 5, No.1, 2016: 293 - 324

Shaddady, Ali, and Moore, Tomoe. 2015. Determinants of Capital Adequacy Ratio in Oil Exporting Countries: Evidence from GCC Commercial Banks. Second Middle East Conference on Global Business, Economics, Finance and Banking (ME15Dubai Conference), 22-24 May, 2015

Shingjergji, Ali., Hyseni, Marsida. 2015. The Determinants of The Capital Adequacy Ratio in The Albanian Banking System During 2007-2014. Internatioal Journal of Economics, Commerce and Management, 3 (1): 110 
Shitawati, F. Artin. 2006. Analisis Faktor-Faktor yang Berpengaruh Terhadap Capital Adequacy Ratio (Studi Empiris : Bank Umum di Indonesia periode 2001-2004), Tesis, Program Studi Magister Manajemen, Program Pasca Sarjana Universitas Diponegoro.

Siamat, Dahlan. 2001. Manajemen Lembaga Keuangan (Edisi Ketiga) :dilengkapi UU No. 7 Tahun 1992 sebagaimana diubah dengan UU No. 10 Tahun 1998. Jakarta: Lembaga Penerbit Fakultas Ekonomi Universitas Indonesia.

Sudirman, I Wayan. 2013. Manajemen Perbankan Menuju Bankir Kovensional yang Profesional (Edisi Pertama). Jakarta: Kencana Prenada Media Group.

Sudiyatno, Bambang dan Asih Fatmawati. 2013. Pengaruh Risiko Kredit Dan Efisiensi Operasional Terhadap Kinerja Bank (Studi Empiris pada Bank yang Terdaftar di Bursa Efek Indonesia. Jurnal Organisasi dan Manajemen, 9 (1):74-86

Sugiyono. 2014. Metode Penelitian Kuantitatif, Kualitatif, dan Kombinasi (Mixed Methods). Bandung : Alfabeta

Surat Keputusan Direksi Bank Indonesia No.30/12/KEP/DIR tentang Tata Cara Penilaian Tingkat Kesehatan BPR

Undang-Undang Nomor 10 Tahun 1998 tentang Perubahan Atas Undang-Undang Nomor 7 Tahun 1992 tentang Perbankan

Undang-Undang Nomor 21 Tahun 2011 tentang Otoritas Jasa Keuangan

Veithzal Rivai. 2006. Credit Manajemen Handbook. 2006. Jakarta; Pt.Raja Grafindo Persada.

Wondifraw, Dawit. 2015. Determinants of Capital Adequacy Ratio: An Empirical Study on Commercial Banks of Ethiopia, Thesis, School of Graduate Studies of Addis Ababa University in Partial Fulfillment of the Requirements for the Degree of Masters of Science in Accounting and Finance.

Wen, Thiam Chiann. 2009. The Determinants of Bank Capital ratio in East Asia, Thesis, The Degree of Master of Business Administration University of Malaya.

Williams, Harley Tega. 2011. Determinants of Capital Adequacy in The Banking Sub-Sector of the Nigeria Economy: Efficacy of Camels. (A Model Specification with Co-Integration Analysis). International Journal of Academic Research in Business and Social Sciences, 1 (3):233-248. 
Yuanjuan, Li. Shishun, Xiao. 2012. Effectiveness of China's Commercial Banks' Capital Adequacy Ratio Regulation A Case Study of The Listed Banks. Interdisciplinary Journal of Contempory Research in Business, 4 (1):5868

NB:

- PAGE PAPER A4

- HEADER FORMAT LIHAT PEDOMAN PENULISAN PADA WEB ojs.unud.ac.id E- Jurnal Manajemen (FONT TNR 11pt)

- HALAMAN FORMAT TNR 11pt PADA OJOK KANAN BAWAH 